\title{
KONFLIK KEAGENAN DALAM PERSPEKTIF KEUANGAN KEPERILAKUAN
}

Abstract: This study aims to provide a theoretical review of the relationship between mental accounting, overconfidence and agency conflict. Agency conflicts can be triggered because the management as an agent does not act in accordance with the interests of the company owners. Agency conflict can be explained through a behavioral financial perspective, namely mental accounting and overconfidence. Judging from the mental accounting aspect, investors may show different behavior on each post or account. In the context of dividend income, shareholders classify dividends as part of their current income account, so shareholders want dividends in a significant amount or amount and are paid regularly. Meanwhile, management as an agent who assumes more information will prioritize current income as a source of internal financing according to the pecking order theory perspective. In the perspective of overconfidence, agency conflict is triggered due to the tendency of company management to give excessive value to its ability to achieve goals, thereby ignoring the probability of risk occurring.

Abstrak: Penelitian ini bertujuan untuk memberikan tinjauan teoritis mengenai keterkaitan mental accounting, overconfidence dan konflik keagenan. Konflik keagenan dapat dipicu karena pihak manajemen sebagai agent tidak bertindak sesuai dengan kepentingan pemilik perusahaan. Konflik keagenan dapat dijelaskan melalui perspektif keuangan keperilakuan yakni mental accounting dan overconfidence. Ditinjau dari aspek mental accounting, investor dimungkinkan menunjukkan perilaku yang berbeda pada setiap post atau account. Dalam konteks pendapatan berupa dividen, pemegang saham mengelompokkan dividen sebagai bagian dari akun current income, maka pemegang saham menghendaki dividen dalam besaran atau jumlah yang signifikan serta dibayarkan secara rutin. Sementara, pihak manajemen sebagai agent yang mengasumsikan memiliki informasi lebih akan mengutamakan current income digunakan sebagai sumber pembiayaan internal sesuai dengan perpektif pecking order theory. Dalam perspektif overconfidence, konflik agensi dipicu karena kecenderungan manajemen perusahaan memberikan nilai yang berlebihan atas kemampuannya dalam mencapai tujuan sehingga mengesampingkan probabilitas terjadinya resiko.

\author{
Axel Giovanni' ${ }^{1}$, Devi Wahyu \\ Utami $^{2}$, Umi Dwi Astuti ${ }^{3}$, \\ Fania $^{4}$ \\ 1, 2, 3, 4 Program Studi \\ Manajemen, Fakultas Ekonomi, \\ Universitas Tidar, Magelang, \\ Jawa Tengah Indonesia
}

axelgiovanni@untidar.ac.id

Keyword: mental accounting, overconfidence, konflik keagenan

Kata Kunci: mental accounting, overconfidence, konflik

keagenan 


\section{Pendahuluan}

Perusahaan

dalam

menajemen, tidak bertindak sesuai dengan kepentingan pemilik perusahaan (Naseem dkk., 2020). Konflik kepentingan terjadi jajaran memiliki manajemen keuangan didefinisikan sebagai kepentingan untuk memperoleh imbalan suatu ikatan kontraktual antara pemilik besar sementara pemilik perusahaan perusahaan (principal) dan pihak manajemen berkepentingan untuk memaksimalkan (agent) dengan tujuan untuk memaksimalkan kesejahteraan serta keuntungan perusahaan. nilai kekayaan pemilik perusahaan. Pada Datta (2020) mengungkapkan bahwa praktiknya, adanya kesenjangan informasi masalah keagenan muncul dari fakta bahwa antara pemilik perusahaan sebagai principal principal sebagai pemasok dana, sementara dengan jajaran manajemen sebagai agent agen mengontrol alokasi dana. Agen dapat dapat memicu konflik kepentingan. Kondisi menggunakan dana tersebut untuk ini dapat direpresentasikan melalui polemik melaksanakan proyek, atau bahkan laporan keuangan Garuda Indonesia. Dilansir mengalihkan dana untuk keperluan pribadi. dari CNN Indonesia (2019), kinerja Oleh karena itu, kajian mengenai konflik keuangan PT Garuda Indonesia mencatatkan keagenan menjadi topik menarik untuk dikaji laba bersih sebesar US\$ 809 ribu pada tahun dari berbagai perspektif manajemen 2018. Kondisi tersebut menuai polemik keuangan terutama keuangan keperilakuan. lantaran pada tahun 2017 Garuda Indonesia Perkembangan literatur keuangan merugi sebesar US\$216,58 juta. Hal ini tradisional telah banyak diselidiki pada membuat dua komisaris Garuda Indonesia beberapadekade terakhir. Kajian dalam menolak untuk menandatangani laporan bidang keuangan semakin berkembang keuangan tahun 2018. Keduanya menolak dengan mempertimbangkan peran psikologi, pencatatan transaksi kerja sama penyediaan emosi dan kesalahan kognitif dalam layanan konektivitas dalam penerbangan pengambilan keputusan. Studi tentang dengan PT Mahata Aero Teknologi dalam keuangan perilaku meningkatkan proses pos pendapatan dikarenakan belum terjadi pengambilan keputusan secara lebih pembayaran dari PT Mahata Aero Teknologi kompleks (Isidore R \& Christie, 2019; Jain et hingga akhir tahun 2018. Dua komisaris al., 2019). Dalam pengambilan keputusan, Garuda telah menyampaikan keberatan atas seringkali pengambil keputusan tidak dapat laporan keuangan tahun 2018, akan tetapi menghindari aspek bias yang menyebabkan berdasarkan rapat pemegang saham pengambil keputusan melakukan kesalahan memutuskan untuk menyetujui laporan (Hidayati, Wahyulina, Wardani, \& Negara, keuangan Garuda Indonesia tahun 2018. 2019). Hal ini dikarenakan adanya aspek Berdasarkan kasus tersebut, menunjukkan rasionalitas dalam pengambilan keputusan bahwa terdapat perbedaan persepsi atas yang dihadapkan pada kondisi ketidakpastian pelaporan pos-pos keuangan serta sehingga pengambil keputusan akan kesenjangan informasi antara manajemen mengedepankan asumsi rasionalitas dengan principal sehingga menjadi pemicu (Hidayati, Wahyulina, Wardani, \& Wardana, konflik keagenan.

Konflik keagenan dijelaskan melalui keperilakuan seperti mental accounting dan agency theory yang pertama kali overconfidence digunakan untuk dikemukakan oleh Jensen \& Meckling menjelaskan konflik agensi (Asri, 2013).

(1976). Teori ini menjelaskan mengenai Mental accounting theory telah pemisahan kepemilikan dan kontrol digunakan untuk menjelaskan perilaku perusahaan. Pemisahan kepemilikan dan irasional dalam berbagai pengaturan, seperti kontrol menyiratkan bahwa keputusan persepsi harga dan perilaku konsumen penting yang dibuat oleh jajaran manajemen penggunaan metode pembayaran yang sebagai agent tidak berdampak besar bagi berbeda, investasi pasar saham, investasi real kekayaan pemegang saham (Sikveland \& estate, dan kredit (Olsen et al., 2019). Zhang, 2020). Dalam suatu perusahaan, Sebagai salah satu komponen behavior agent dalam hal ini adalah jajaran finance, mental accounting merujuk pada 
kecenderungan pemilik untuk tugas" yang memiliki tanggung jawab untuk mengelompokkan keuangan dalam post-post mengelola perusahaan dengan tujuan akun yang berbeda-beda dengan berdasar memaksimalkan nilai bagi kesejahteraan pada kriteria subjektif (Hidayati, Wahyulina, pemegang saham. Sehingga aspek Wardani, \& Wardana, 2019). Dalam overconfidence dalam perspektif manajemen pengambilan keputusan, mental accounting perusahaan dapat memicu adanya konflik berguna untuk melacak aktivitas keuangan keagenan dengan pemilik perusahaan.

dan strategi untuk mengatasi masalah Penelitian ini menjelaskan mengenai pengendalian terhadap pengeluaran dan konflik agensi yang ditinjau dari aspek konsumsi. Mental accounting memberikan keuangan keperilakuan. Penelitian ini penjelasan mengenai proses keputusan bertujuan untuk mengembangkan kajian kognitif dalam pengambilan keputusan yang teoritis mengenai keterkaitan mental diberikan. Individu dengan skor mental accounting, overconfidence dan konflik accounting yang lebih besar melaporkan keagenan. Penelitian ini dilakukan guna perencanaan keuangan yang lebih jelas mengembangkan kerangka penelitian secara (Olsen et al., 2019). Konflik agensi melalui konseptual mengenai konflik keagenan perspektif mental accounting dipicu karena melalui perspektif mental accounting dan adanya perbedaan perlakuan terhadap mental overconfidence. Secara teoritis, penelitian ini account oleh pemegang saham dan pihak memberikan kontribusi berupa sumbangan manajemen hubungannya dengan pembagian pemikiran untuk memperkaya literatur dividen.

Konsep overconfidence menjelaskan mengenai sikap individu yang terlalu percaya diri, terlalu overestimate mengenai kemampuan subjektif, serta kehandalan informasi yang mereka peroleh (Tekin, 2018; Vitanova, 2019). Perilaku overconfidence dapat terjadi kepada setiap pengambil keputusan, termasuk investor dan manajer. Dari sudut pandang investor, perilaku overconfidence merupakan sikap terlalu percaya diri, akan cenderung melakukan sebuah investasi dalam aset yang telah dipahami secara baik, dimana investor sudah menemukan kepercayaan informasi mengenai perusahaan tersebut (Paramita, 2018). Sedangkan bagi manajer, perilaku overconfidence sering dikaitan dengan proses pengambilan keputusan suatu perusahaan (Sadaqat et al., 2018), yang didasarkan pada intusi serta kemampuan dalam memprediksi peningkatan perusahaan dari waktu ke waktu seperti keputusan investasi perusahaan. Menurut Daryaei et al., (2020) manajer yang memiliki tingkat kepercayaan diri yang tinggi akan memprediksikan laba atas investasi lebih tinggi dari yang sebenarnya dan relatif mengesampingkan risiko yang kemungkinan dihadapi sehingga menimbulkan konsekuensi berbahaya bagi para pemangku kepentingan. Secara hubungan kontraktual, manajemen perusahaan berada dalam ikatan "kontrak keuangan.

\section{Bahasan Utama}

Keuangan keprilakuan didefiniskan sebagai suatu pendekatan yang mempelajari perilaku para pengambil keputusan krusial dalam perusahaan. Pendapat lain dikemukakan oleh DeBondt et al. (2010) bahwa keuangan keprilakuan lahir karena masih sedikit bukti empiris yang mendukung teori-teori keuangan yang sudah ada. Asumsi yang menjadi dasar keuangan keprilakuan adalah dalam kondisi atau aspek tertentu proses pengambilan keputusan oleh jajaran manajemen puncak perusahaan mungkin tidak didasarkan pada pertimbangkan rasional..

\section{Pengembangan Implikasi Mental Accounting dengan Konflik Keagenan}

Mental accounting merupakan salah satu faktor penyebab konflik yang terjadi antara principal dengan agent. Olsen et al. (2019) mendefinisikan mental accounting sebagai serangkaian aspek kognitif yang membantu mengatur aktivitas keuangan serta memfasilitasi pengelolaan uang. Menurut Huang et al. (2020), mental accounting mengacu pada pemisahan psikologis mengenai sumber daya dan bagaimana melacak penggunaan sumber daya. Mental 
accounting secara lebih luas didefinisikan diatasi dengan membangun akun mental dan sebagai serangkaian operasi kognitif yang pengklasifikasian biaya-biaya dengan tepat digunakan oleh individu maupun perusahaan (Huang et al., 2020). Agen membagi untuk mengatur, mengkategorikan, melacak kekayaan perusahaan kedalam akun yang dan mengevaluasi aktivitas keuangan memiliki tujuan berbeda. Untuk setiap akun, (Thaler, 1999; Mahastanti \& Wiharjo, 2012; agen memaksimalkan pengembalian yang Liu \& Chiu, 2015; Dewanti et al., 2018). diharapkan sesuai dengan

Mental accounting seringkali digunakan menginvestasikan kekayaan sepenuhnya, dalam teori portofolio serta pemilihan serta (b) probabilitas pengembalian kurang portofolio (Xue et al., 2019; Chang et al., dari atau sama dengan berapa ambang batas 2020).

Perspektif ekonomi keperilakuan batas (Alexander et al., 2020).

menjelaskan bahwa pada dasarnya individu Mental accounting dapat ditunjukkan mengevaluasi hasil baik secara terpisah oleh penilaian yang berbeda oleh individu melalui mental account maupun secara sehingga memiliki kecenderungan bersama-sama. Teori mengenai mental pengambilan keputusan yang berbeda pula accounting merupakan sebuah pendekatan (Song et al., 2018). Penetapan pilihan dari aspek keuangan keperilakuan serta tersebut seringkali menunjukan tindakan pengambilan keputusan-keputusan yang yang tidak rasional dalam pengambilan menjelaskan implementasi proses kognitif keputusan yang membentuk pilihan oleh individu untuk mengukur pendapatan keputusan investasi dengan potensi dan pengeluaran terutama berfokus terhadap keuntungan maupun kerugian (Hidayati, aktivitas keuangan dan anggaran tertentu Wahyulina, Wardani, \& Wardana, 2019). (Olsen et al., 2019; Abdani \& Nurdin, 2019). Individu dengan skor mental accounting Mental accounting menjadi kerangka hasil yang lebih besar melaporkan perencanaan yang menentukan (i) himpunan hasil dasar keuangan yang lebih jelas (Olsen et al., yang dievaluasi bersama dan cara di mana 2019).

mereka digabungkan serta (ii) hasil referensi yang dianggap netral atau normal (Koch \& Nafziger, 2016).

Mental account dapat menunjukkan cara pandang individu dalam memperlakukan kekayaannya dengan

Mental accounting menjadi pemicu melihat keterkaitan tersebut terhadap a) konflik keagenan dalam konteks pembagian kapabilitas menciptakan laba saat ini deviden baik dari besaran dividen maupun (current income), b) kekayaan yang dimiliki bentuk pembagian dividen (Asri, 2013). saat ini, dan c) kapabilitas menciptakan laba Mental accounting menjadi fokus utama di masa depan (future income) (Hidayati, dalam pengambilan keputusan keuangan. Wahyulina, Wardani, \& Wardana, 2019). Mental accounting membentuk semacam Dalam konsep mental account, investor mental account untuk arus kas baik arus kas dimungkinkan menunjukkan perilaku yang masuk maupun arus kas keluar. Elemen berbeda pada setiap post atau account. dasar mental accounting yakni adanya Mental accounting merepresentasikan pengelompokkan dana ke dalam suatu akun kecenderungan investor untuk atau kategori pelaporan dengan tujuan untuk mengelompokkan keuangan pada post atau mengontrol keputusan pengeluaran serta akun yang berbeda dengan berdasar terhadap kecenderungan marginal dalam kegiatan kecenderungan subjektif seperti sumber konsumsi pada seluruh akun. Mental pendanaan dan maksud pemanfaatan accounting berperan dalam pengambilan pendapatan. Dalam konteks pendapatan keputusan sebagai perangkat pengendalian berupa dividen, pemegang saham diri untuk mengontrol pengeluaran dan memperlakukan dividen sebagai pendapatan konsumsi yang berlebihan, serta membantu saat ini (current income) yang akan dipakai dalam pencapaian tujuan. Meskipun guna memenuhi pembiayaan saat ini. demikian, mental accounting yang tidak Sebaliknya, capital gain diasumsikan fleksibel menyebabkan timbulnya biaya dan sebagai bagian dari future income yang kinerja yang kurang maksimal. Hal ini dapat digunakan kemudian hari (Asri, 2013). 
Ketika pemegang saham mengelompokkan mengambil sebuah keputusaan. dividen sebagai bagian dari akun current Overconfidence menyebabkan seseorang income, maka pemegang saham akan melebihkan-lebihkan pengetahuan, menghendaki dividen dalam besaran atau meremehkan sebuah risiko, dan membesarjumlah yang signifikan serta dibayarkan besarkan kemampuan prediksi dan secara rutin. Sementara, pihak manajemen kehandalan informasi terhadap sesuatu hal sebagai agent yang mengasumsikan memiliki (Tekin, 2018). Dengan demikian, informasi lebih akan berpikiran yang overconfidence didefinisikan sebagai kondisi berbeda.

Zakiyah (2017) mengungkapkan informasi yang telah diperolehnya atas dasar bahwa kepemilikan saham oleh pihak kemampuan dan pengetahuan sehingga dapat manajemen memiliki hubungan negatif mengesampingkan sebuah risiko yang terhadap pembagian dividen. Hal ini mungkin terjadi (Kartika \& Iramani, 2013; mengindikasikan bahwa perusahaan dengan Pan et al., 2019; Liang et al., 2019; Iyer et kepemilikan saham oleh manajemennya al., 2017; Gul et al., 2020; He et al., 2019; besar memiliki kecenderungan untuk Dwi Rakhmatulloh \& Asandimitra, 2019). membagikan dividennya dalam jumlah yang Salah satu faktor yang menyebabkan rendah. Menurut Prasetyo (2013), perilaku overconfidence muncul yakni pembayaran dividen yang dilakukan advices, artinya semakin banyak seseorang perusahaan dapat menjadi bentuk mendapatkan informasi dan saran dari orang pengendalian terhadap konflik keagenan. yang berpengalaman, maka seseorang Perspektif pecking order theory tersebut akan semakin tinggi tingkat menyatakan bahwa manajemen perusahaan kepercayaan dirinya (Kartini \& Dwi akan menggunakan keuntungan bersih Apriliani Setiawan, 2017). Dengan demikian semaksimal mungkin untuk membiayai perbedaan antara literatur keuangan kegiatan investasi (Asri, 2013). Perilaku tradisional dengan perspektif keuangan tersebut sesuai dengan paradigma pecking keperilakuan berpengaruh terhadap order theory yang menjelaskan bahwa pengambilan keputusan.

perusahaan memiliki hierarkis dalam Teori keuangan tradisional menyatakan menentukan keputusan pendanaan dengan bahwa keputusan seorang dalam berdasar pada masalah informasi asimetris menginvestasikan sejumlah uangnya (Myer, 1984; Myers \& Majluf, 1984; merupakan keputusan yang rasional, Giovanni et al., 2020). Jajaran manajemen sementara menurut Kartini \& Dwi Apriliani cenderung memiliki informasi yang lengkap Setiawan, (2017) mengungkapkan bahwa mengenai nilai perusahaan dibandingkan investor dapat melakukan tindakan dengan pemegang saham atau investor. irrasional. Pihak manajemen perusahaan, Kondisi tersebut memicu pihak manajemen yakni manajer memiliki informasi-informasi untuk mengimplementasikan hierarki yang dipercayai dan digunakan sebagai pembiayaan dengan menggunakan bahan prediksi dalam pengambilan keuntungan bersih untuk pembiayaan keputusan perusahaan, salah satunya yakni investasi. Sehingga besaran dividen yang keputusan investasi. Dalam konteks dibagikan relatif kecil atau bahkan tidak ada investasi, perusahaan akan menghadapi pembagian dividen. Hal itulah yang akan risiko-risiko yang mungkin terjadi, sehingga memperbesar potensi konflik agensi.

\section{Pengembangan Implikasi Overconfidence dengan Konflik Keagenan} peran manajer dalam mengambil keputusan secara tepat dan tepat sangat di perlukan.

Perspektif agency theory menjelaskan bahwa agen atau manajer dipilih oleh para pemegang saham untuk mengelola

Dila Afriani \& Halmawati (2019) perusahaan dan menjalankan serangkaian menyatakan bahwa overconfidence tugas terpisah sesuai dengan kepentingan didefinisikan sebagai suatu kecenderungan principal atau pemegang saham (Zogning, dimana seseorang terlalu yakin terhadap 2017). Hubungan kontraktual yang kemampuan serta pengetahuannya dalam terjadinya antara principal dan agent sebagai 
pihak yang memberikan layanan atas nama mereka, sehingga principal akan memberikan kewenangan kepada agent untuk mengelola perusahaan serta memprediksi masa depan. Kontrak kerja secara tidak langsung menekankan para agent untuk bertindak sesuai dengan kepentingan pemilik dan memaksimalkan nilai pemegang saham. Dengan demikian, terdapat keterkaitan antara perilaku overconfidence terhadap konflik agensi berdasarkan keputusan investasi manajer.

Jain et al. (2019) mengungkapkan bahwa terlalu percaya diri membuat manajer melebih-lebihkan aspek kognitif, ketrampilan, ketepatan informasi dalam pencapaian tujuan, sehingga merasa penilaian mereka lebih dapat diandalkan daripada orang lain. Malmendier \& Tate, (2015) mengungkapkan bahwa overconfidence dapat berpengaruh terhadap pengambilan keputusan seperti investasi, merger, pilihan pembiayaan dan pembayaran dividend. Menurut Tekin (2018), semakin tinggi tingkat kepercayaan diri akan menyebabkan rendahnya tingkat pengembalian atas investasi, karena manajer salah mengartikan proyek investasi mereka dengan ekspektasi manajer yang tinggi. Risiko yang timbul dari rendahnya pengembalian investasi akan berpengaruh terhadap pembagian dividen kepada para pemegang saham. Inilah yang menjadi dasar pangkal konflik keagenan antara manajer dengan pemegang saham. Sesuai dengan asumsi pendapatan dividen atas pengembalian investasi, para pemegang saham menghendaki pembagian dividen dalam jumlah yang signifikan dan secara rutin dapat dibagikan (Asri, 2013).

\section{Skema Hubungan antar Variabel}

Hasil dan pembahasan

dalam penelitian memberikan penjelasan mengenai pengembangan implikasi mental accounting dengan konflik agensi dan overconfidence dengan konflik agensi. Hubungan mengenai mental accounting, overconfidence dan konflik keagenan dapat direpresentasikan melalui fungsi matematis dan kerangka konseptual berikut:
Kerangka konseptual dapat digambarkan sebagai berikut:

\section{Gambar 1. Kerangka Pemikiran Teoritis}

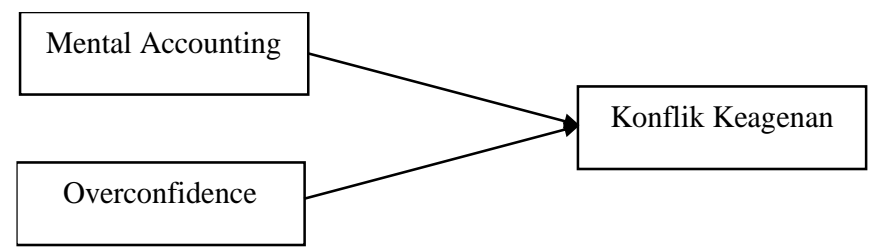

Sumber: Hasil kajian literatur

\section{Kesimpulan, Keterbatasan, dan Saran}

\section{Kesimpulan}

Penelitian ini bertujuan untuk memgembangkan kajian teoritis serta kerangka konseptual mengenai konflik keagenan melalui perspektif mental accounting dan overconfidence. Dalam persepktif mental accounting, konflik keagenan dapat dipicu karena ecenderungan subjektif dalam pengelompokkan dana, seperti dalam konteks pendapatan berupa dividen. Individu dengan skor mental accounting yang lebih besar dinilai dapat melaporkan perencanaan keuangan secara lebih jelas. Dalam perspektif overconfidence, konflik keagenan dipicu karena kecenderungan manajemen perusahaan memberikan nilai yang berlebihan atas kemampuannya dalam mencapai tujuan sehingga mengesampingkan probabilitas terjadinya resiko. Dengan demikian tujuan penelitian telah tercapai. Secara teoritis, penelitian ini memberikan sumbangan pemikiran untuk memperkaya literatur keuangan. secara praktis, penelitian ini memberikan sumbangan pemikiran yang dapat dijadikan pertimbangan bagi perusahaan guna meminimalisir konflik keagenan terutama melalui perspektif mental accounting dan overconfidence

Konflik Keagenan $=f($ Mental Accounting, Overconfidence $)$ 


\section{Keterbatasan dan Saran}

Penelitian ini terbatas pada kajian mental accounting, overconfidence dan konflik keagenan melalui studi kepustakaan. Penelitian selanjutnya diharapkan dapat membuktikan secara empiris mengenai hubungan mental accounting, overconfidence dan konflik keagenan berdasarkan data di lapangan.

\section{DAFTAR PUSTAKA}

Abdani, F., \& Nurdin, F. (2019). Kausalitas Mental Accounting dan Pengambilan

Keputusan Investasi Mesin Produksi: Suatu Studi Eksperimen. Akuntabilitas, 12(2), 145-156 https://doi.org/10.15408/akt.v12i2.11703

Alexander, G. J., Baptista, A. M., \& Yan, S. (2020). Portfolio selection with mental accounts: An equilibrium model with endogenous risk aversion. Journal of Banking and Finance, 110(xxxx), 105599. https://doi.org/10.1016/j.jbankfin.2019.07. 019

Asri, M. (2013). Keuangan Keperilakuan (1st Editio). BPFE-Yogyakarta.

Chang, J., Sun, L., Zhang, B., \& Peng, J. (2020). Multi-period portfolio selection with mental accounts and realistic constraints based on uncertainty theory. Journal of Computational and Applied Mathematics, 377, 112892. https://doi.org/10.1016/j.cam.2020.112892

Daryaei, A. A., Fattahi, Y., Sadeqi, H., \& Hasani, R. (2020). Management Characteristics and Cost Stickiness : An Examination Based on Agency Theory. 2003. https://doi.org/10.22097/eeer.2020.230712. 1156

Datta, B. (2020). Investment timing, agency and overconfidence. Operations Research Letters, 48(3), 286-290. https://doi.org/10.1016/j.orl.2020.03.008
DeBondt, W., Forbes, W., Hamalainen, P., \& Gulnur Muradoglu, Y. (2010). What can behavioural finance teach us about finance? Qualitative Research in Financial Markets, 2(1), 29-36. https://doi.org/10.1108/1755417101104237 1

Dewanti, P. W., Priantinah, D., K, W. A., Subthy, T. R., \& Hasan, A. A. (2018). Mental Accounting Dalam Proses Pengambilan Keputusan Investasi. Jurnal Akuntansi, 6(1), 75-87.

Dila Afriani \& Halmawati. (2019). Pengaruh cognitive dissonance bias, overconfidence bias dan herding bias terhadap pengambilan keputusan investasi. 1(4), 1650-1665.

Dwi Rakhmatulloh, A., \& Asandimitra, N. (2019). Pengaruh Overconfidence, Accounting Information, dan Behavioural Motivation Terhadap Keputusan Investasi di Kota Surabaya. Jurnal Ilmu Manajemen (JIM), 7, 796-806.

Giovanni, A., Utami, D. W., \& Widiyaningrum, E. (2020). Size, Growth, Profitability and Capital Structure. Jurnal REKOMEN, 4(1), 81-90.

Gul, F. A., Krishnamurti, C., Shams, S., \& Chowdhury, H. (2020). Corporate social responsibility, overconfident CEOs and empire building: Agency and stakeholder theoretic perspectives. Journal of Business Research, 111(January), 52-68. https://doi.org/10.1016/j.jbusres.2020.01.0 35

He, Y., Chen, C., \& Hu, Y. (2019). Managerial overconfidence, internal financing, and investment efficiency: Evidence from China. In Research in International Business and Finance (Vol. 47). Elsevier B.V. https://doi.org/10.1016/j.ribaf.2018.09.010

Hidayati, S. A., Wahyulina, S., Wardani, L., \& Negara, I. K. (2019). Mental Accounting Dan Dampaknya Terhadap Kinerja Perusahaan Melalui Penempatan Modal 
Kerja Pada Usaha Kecil Dan Menengah Di Pulau Lombok. Journal of Chemical Information and Modeling, 53(9), 16891699.

Hidayati, S. A., Wahyulina, S., Wardani, L., \& Wardana, I. K. (2019). Mental Accounting Dan Dampaknya Terhadap Kinerja Perusahaan Melalui Penempatan Modal Kerja Pada Usaha Kecil Dan Menengah Di Pulau Lombok. JRM, 16(1), $1-19$.

Huang, J., Antonides, G., \& Nie, F. (2020). Is mental accounting of farm produce associated with more consumption of ownproduced food? Journal of Behavioral and Experimental Economics, 88(August), 101594. https://doi.org/10.1016/j.socec.2020.10159 4

Indonesia, C. (2019). Kronologi Kisruh Laporan Keuangan Garuda Indonesia. https://www.cnnindonesia.com/ekonomi/2 0190430174733-92-390927/kronologikisruh-laporan-keuangan-garuda-indonesia

Isidore R, R., \& Christie, P. (2019). The relationship between the income and behavioural biases. Journal of Economics, Finance and Administrative Science, 24(47), 127-144. https://doi.org/10.1108/JEFAS-10-20180111

Iyer, S. R., Sankaran, H., \& Nejadmalayeri, A. (2017). CEO overconfidence and agency cost of debt: An empirical analysis of CEO turnover events. North American Journal of Economics and Finance, 42, 300-313.

https://doi.org/10.1016/j.najef.2017.07.01

Jain, J., Walia, N., \& Gupta, S. (2019). Evaluation of behavioral biases affecting investment decision making of individual equity investors by fuzzy analytic hierarchy process. Review of Behavioral Finance, 12(3), 297-314. https://doi.org/10.1108/RBF-03-2019-0044
Jensen, M. C., \& Meckling, W. H. (1976). Theory of The Firm: Managerial Behavior, Agency Costs and Ownership Structure. Journal of Financial Economics, 3(4), 305-360. https://doi.org/10.1016/0304405X(76)90026-X

Kartika, N., \& Iramani, R. (2013). Pengaruh Overconfidence, Experience, Emotion Terhadap Risk Perception Dan Risk Attitude Pada Investor Pasar Modal Di Surabaya. Journal of Business and Banking, 3(2), 177.

https://doi.org/10.14414/jbb.v3i2.235

Kartini \& Dwi Apriliani Setiawan. (2017). faktor-faktor yang Mempengaruhi Perilaku Overconfidence investor saham di Yogyakarta. 4(1), 36-46.

Koch, A. K., \& Nafziger, J. (2016). Goals and bracketing under mental accounting. Journal of Economic Theory, 162, 305351. https://doi.org/10.1016/j.jet.2016.01.001

Liang, Q., Ling, L., Tang, J., Zeng, H., \& Zhuang, M. (2019). Managerial overconfidence, firm transparency, and stock price crash risk: Evidence from an emerging market. China Finance Review International, 10(3), 271-296. https://doi.org/10.1108/CFRI-01-20190007

Liu, H. H., \& Chiu, Y. Y. (2015). Sales framing, mental accounting, and discount assignments. Asia Pacific Management Review, 20(4), 201-209. https://doi.org/10.1016/j.apmrv.2015.01.00 2

Mahastanti, L. A., \& Wiharjo, K. K. (2012). Mental Accounting Dan Variabel Demografi : Sebuah Fenomena Pada Penggunaan Kartu Kredit. Kinerja Journal of Business and Economics, 16(2), 89-102. 
Malmendier, U., \& Tate, G. (2015). Behavioral CEOs: The role of managerial overconfidence. Journal of Economic Perspectives, 29(4), 37-60. https://doi.org/10.1257/jep.29.4.37
Sadaqat, S., Shah, H., Xinping, X., Khan, M. A., \& Harjan, S. A. (2018). Investor and Manager Overconfidence Bias and Firm Value: Micro-level Evidence from the Pakistan Equity Market. 8(5), 190-199.

Myer, S. C. (1984). The Capital Structure Sikveland, M., \& Zhang, D. (2020).

Puzzle. The Journal of Finance, 39(3), 575-592.

Myers, S. C., \& Majluf, N. S. (1984).

Corporate Financing and Investment

Decisions When Firms Have Information

The Investors Do Not Have. Journal of Song, Y., Chen, J., Yang, Y., Jia, C., \& Su, J. Finance Economics, 13(2), 187-221. https://doi.org/10.1016/S00404039(00)91429-1

Naseem, M. A., Lin, J., Rehman, R. ur, Ahmad, M. I., \& Ali, R. (2020). Does capital structure mediate the link between Tekin, B. (2018). Overconfidence And Effect On CEO characteristics and firm performance? Management Decision, 58(1), 164-181. https://doi.org/10.1108/MD-05-2018-0594

Olsen, J., Kasper, M., Kogler, C., Determinants of capital structure in the Norwegian salmon aquaculture industry. Marine Policy, 119(May), 1-7. https://doi.org/10.1016/j.marpol.2020.1040 61 (2018). A dual-channel supply chain model considering supplier's mental accounting and retailer's fairness concerns. Procedia Computer Science, 139, 347-355. https://doi.org/10.1016/j.procs.2018.10.280

Muehlbacher, S., \& Kirchler, E. (2019). Thaler, R. H. (1999). Mental Accounting

Mental accounting of income tax and value Matters. Journal of Behavioral Decision added tax among self-employed business owners. Journal of Economic Psychology, $70,125-139$.

Making, 12, 183-206.

https://doi.org/10.1111/j.1475-

097X.1994.tb00413.x

https://doi.org/10.1016/j.joep.2018.12.007

Pan, A., Liu, W., \& Wang, X. (2019). Managerial overconfidence, debt capacity and merger \& acquisition premium. Nankai Business Review International, 10(4), 570590. https://doi.org/10.1108/NBRI-042019-0016

Paramita, R. A. S. (2018). BIAS KOGNITIF DAN KEPRIBADIAN INDIVIDU: STUDI PERILAKU INVESTOR MUDA DI SURABAYA. 9(2).

Prasetyo, T. (2013). Dividen, Hutang, Dan Kepemilikan Institusional Di Pasar Modal Indonesia: Pengujian Teori Keagenan. Jurnal Dinamika Manajemen, 4(1), 10-22. https://doi.org/10.15294/jdm.v4i1.2420
Vitanova, I. (2019). Nurturing overconfidence: The relationship between leader power, overconfidence and firm performance. The Leadership Quarterly, June 2018, 101342. https://doi.org/10.1016/j.leaqua.2019.1013 42

Xue, L., Di, H., Zhao, X., \& Zhang, Z. (2019). Uncertain portfolio selection with mental accounts and realistic constraints. Journal of Computational and Applied Mathematics, 346, 42-52. https://doi.org/10.1016/j.cam.2018.06.049 
Journal Accounting and Finance

Edisi Vol. 5 No. 1 Maret 2021

Universitas Telkom

Zakiyah, T. (2017). Analisis konflik Agency

Teory dan pengaruhnya terhadap kebijakan

Dividen pada perusahaan yang tergabung

dalam LQ 45 (Studi kasus tahun 2011-

2015). Jurnal Ilmiah Akuntansi Dan

Keuangan, 6(01), 1-28.

Zogning, F. (2017). Agency Theory : A Critical

Review. 9(2), 1-8. 